\title{
NATIONALIZATION AND COMPENSATION A COMPARATIVE APPROACH
}

\author{
SEYMOUR J. RUBIN*
}

$\mathrm{O}$ N July I9, I948, the Department of State announced that agreement had been reached with Yugoslavia on a settlement of the claims of American nationals arising out of Yugoslav nationalization of their property. ${ }^{x}$ On September 28 , I949, it was announced in London that an agreement between Britain and Czechoslovakia had been reached, under which claims of British nationals arising out of $\mathrm{Czech}$ nationalizations would be settled. ${ }^{2}$ Analysis of the two agreements will reveal some important similarities and differences. Both the similarities and the differences are important signposts for the American businessman with foreign interests and for his lawyer.

\section{I}

Although expropriation of private property is an ancient practice, it is not one to which the world has become accustomed. Problems of the sort which now arise out of expropriations or nationalizations are not dissimilar to those which arose thousands of years ago. It was argued in $37^{\circ}$ B.c. that liberation of the Spartan slaves was theft of private property. ${ }^{3}$ Probably research would disclose even earlier manifestations of the problem of compensation for property taken away from the owner by governmental action. The long history of the problem has seen the development of some rules; but they have not, as can be seen only too clearly from modern examples, always settled the disputes.

* Member of the Illinois and District of Columbia Bars.

I See United States Dept. of State Bull., Vol. r9, No. 473, at I37 (July 25, I948) for the text of the agreement. A simultaneous lend-lease settlement agreement was also made. Legislation designed to implement this and future compensation agreements has been approved by both Houses of the 8ist Congress, but has not, as of February 21, 1950, become law; see note $4 \mathrm{I}$ infra. This articles does not deal, except incidentally, with the proposed legislation, as distinguished from the agreement.

2 See British Treaty Series No. 60, Cmd. 7797 (H.M. Stationery Office, I949) for text of the agreement. At the same time, the British government released an "Agreement . . . relating to the Settlement of certain Inter-Governmental Debts" (British Treaty Series No. 6I, Cmd. 7798 [H.M. Stationery Office, I949]) and a "Trade and Financial Agreement" (British Treaty Series No. 62, Cmd. 7799 [H.M. Stationery Office, 1949]). The British subsequently, in December, I949, reached an agreement with Yugoslavia, similar to the British-Czech agreement. The text of the agreement, however, was not available at the time of writing.

3 The same argument was apparently not directed against the freeing of the slaves in the United States. See I Hyde, International Law 7 I2 n. Io (I945). 
The problem was somewhat simpler in the pre-World War I days. Expropriation was then an isolated and a rather uncommon phenomenon. ${ }^{4}$ When a government, for one reason or another, did expropriate private property, whether of its own or of foreign nationals, the rules of international and of national law generally coincided: payment was to be made promptly. The practice might deviate from the rule, and the amount to be paid might be disputed. But the principle of payment was hardly questioned. The international law rule was formalized as calling for prompt, adequate and effective payment. ${ }^{5}$

After World War I, however, expropriation tended to lose its purely incidental character. Expropriation, particularly of the property of foreign nationals, sometimes was a point of major national policy. The agrarian and petroleum expropriations of Mexico were entirely different in character and significance from the expropriation of a building for a postoffice or a right of way for a railroad. ${ }^{6}$ Thus, the dispute between Mexico and the United States gave rise to stern exchanges of diplomatic correspondence; and its effects are still felt. The postoffice or right-of-way examples would be in no sense a derogation from the usual rights of foreign nationals and foreign-owned property. ${ }^{7}$ In the Mexican oil case, the desire of Mexico to redistribute its farm lands and to bring its oil industry under public control and ownership was a basic policy which was considered to be more important than the rights of private foreign owners. ${ }^{8}$

As expropriation or nationalization becomes more basic to national pol-icies, so the problem of settlement becomes more difficult. Partially this is so because the desire to put an industry, previously privately owned, under public control and ownership itself carries implications of deviation from usually accepted (in the United States, at any rate) standards; and partially because it is obviously harder for any government to handle a (I948).

4 Doman, Postwar Nationalization of Foreign Property in Europe, 48 Col. L. Rev. Ir25

5 Note of Secretary of State Hull of August 22, 1938 , Press Releases, Dept. of State, Vol. I9, No. 465 , at 138 .

${ }^{6}$ See 3 Bishop, Cases and Materials on International Law 5 I5 et seq. (1949), quoting exchanges between Mexico and the United States.

7 This was forcefully pointed out by Secretary of State Hull in his note to the Mexican ambassador of July 2I, 1938, quoted in Bishop, op. cit. supra note 6, at $5^{15}$.

${ }^{8}$ The note of the Mexican ambassador of August 3, 1938, thus stated: "On the one hand, there are weighed the claims of justice and the improvement of a whole people, and on the other hand, the purely pecuniary interests of some individuals." The note also pointed out the importance of the program of agrarian reform to the future of Mexico and stated: "[T] he future of the nation could not be halted by the impossibility of paying immediately the value of properties belonging to a small number of foreigners who seek only a lucrative end." Bishop, op. cit. supra note 6 , at 518 . 
compensation problem which bulks importantly in the national budget than one which is financially insignificant to the nation.

Economic, political and social factors thus are injected into present nationalization-compensation problems. As a result, a variety of complications exist in a situation which, in certain regards, has been thought to be fairly clear. All authorities agree that a sovereign state has the right to expropriate, or nationalize, the property not only of its own but of foreign nationals. The rule of international law is, however, that the taking of the private property of foreign nationals is accompanied by the obligation to make prompt, adequate and effective payment.9 The United States declared in its note to Mexico on April 3, I940, that the right to nationalize is "coupled with and conditional on the obligation to make adequate, effective and prompt compensation." Charles Cheney Hyde has also sug-

9 There is not a great deal on this point in the standard texts. It has been suggested that "[I]t is probable that text-writers have given little attention to the status of the private property of aliens in time of peace because the inviolability of such property was so generally recognized." Bullington, Problems of International Law in the Mexican Constitution of 1917 , 21 Am. J. Int. L. 685, 695 (I927). In support of this assumption, it may be noted that in IgI8, all governments represented in Russia protested the confiscation of the private property of their nationals as being contrary to international law.

The question of when there has been a taking of property which brings into play the clear rule of the duty to make for compensation is one, however, which is not without difficulty. A state may exercise its "police power," as in the freeing of slaves or the prohibition of the manufacture of intoxicating liquor, without being compelled to compensate, under the principles of international law, foreign nationals whose property is thus affected or destroyed. Bullington, in the article cited in this note, points out this problem, and indicates the problem of clear definition in the shadow-land between the two black-letter principles. A real and substantive aspect of the problem arises in those present cases in which "creeping nationalization" rather than outright expropriation has been used. When does a combination of labor laws, price controls and government supervision reach the point of being an effective taking of the property of a foreign national, even though he retains nominal title? For a considerable time, this was actually the problem faced by the United States with respect to Hungarian actions affecting American properties in Hungary -an issue which perhaps fortunately was resolved by expropriation.

One authority has suggested a test other than whether there has been a taking. Speaking of the freeing of the American slaves and the prohibition of the manufacture of liquor, Fenwick states that "... in both cases the losses imposed by the law upon aliens were negligible compared to those imposed upon citizens; and in both cases alien owners of the property had warning of its probable destruction." Fenwick, International Law 289 ( $3 \mathrm{~d}$ ed. I948). The facts that local nationals are even more grievously mistreated than aliens, or that the aliens can see disaster from afar off, hardly seem to be the basis for a valid departure from the rule of compensation when property is taken. If the Fenwick distinction were valid, indeed, there would probably be little basis for compensation claims arising out of the recent Communist nationalizations of Eastern Europe.

It seems clear that the difficulty lies rather in the field between a taking and an exercise of police power; that, in a border-line case, the phrases indicate results more than they solve problems. Consideration of the "creeping nationalization" problem, however, lies outside the direct line of this article, since in the cases herein considered, there has been a direct and clear transfer of ownership from the former private owner to the nationalizing government. The literature which has dealt with "takings," however, might well be supplemented by an inquiry into the meaning of that term in the field of international law. 
gested that the power to take is conditional on the making of payment. ${ }^{\text {xo }}$ Whether many governments other than that of the United States would agree that the right to take private property is conditioned on the ability to make payment in foreign exchange acceptable to the previous owner is questionable. $^{\text {II }}$ But, in general, the rule of prompt, adequate and effective payment as a right of the expropriated owner is recognized.

If the law has been fairly clear, the present practice is not. A number of facts intrude on the settlement and solution of problems in this field. The two most important of these facts are (a) the almost omnipresent existence of exchange difficulties-particularly, shortages of dollar exchange; and (b) the attitude of hostility toward private investors of most of the governments which have recently undertaken large scale nationalization of private foreign investment.

The exchange difficulty means that even friendly governments, which are generally like-minded with the United States in their view of the law, define the phrase "effective compensation" differently than does the United States. Thus, in the negotiation of the investment provisions of the Charter of the International Trade Organization, the view was stated by such countries as Canada that the power to take private property for public purposes could not be made conditional on the power to make payment to American investors in dollars-that is, in the currency of the investor. ${ }^{12}$ Exactly how such countries would formulate the rule of international law is not clear. While the view of many delegates at the ITO conferences seemed to be that shortages of dollars or other foreign exchange did not detract from governmental power to expropriate, those delegates cannot be said to have advocated the theory that local currency compensation would, under any and all circumstances, be sufficient. Definition of views, in this regard, was conspicuously lacking, but it might be fairly said that most delegations felt that the compensation must be something which was useful to and useable by the expropriated owner. ${ }^{13}$ Per-

10 Hyde, Compensation for Expropriation, 33 Am. J. Int. L. Io8, II 2 (1939).

II This, of course, was the heart of the controversy with Mexico.

r Compare Report of the Second Session of the Preparatory Committee of the United Nations Conference on Trade and Employment 13, note to Art. I2, Cmd. 72 I2 (H.M. Stationery Office, 1947): "... The extent to which transfers of ... payment [of compensation for expropriated properties] into other currencies are to be allowed is for determination by the Member government in accordance with its general foreign exchange policy maintained consistently with the Articles of Agreement of the International Monetary Fund."

${ }_{3}$ Compare Wilcox, A Charter for World Trade 146 et seq. (r948). In this connection, an interesting speculation is the rule which might be pressed if the property of a national of a softcurrency country were being expropriated in a country which had a hard-or harder-currency. Would the expropriating country insist on the right to compensate in the national 
haps they would concede that there was an obligation, over a period of time, to make foreign exchange available for the liquidation of local currency compensation. Perhaps they would argue, on the other side, that as long as capital withdrawals from a country were limited by exchange controls - and even by some provisions of the Articles of Agreement of the International Monetary Fund ${ }^{x_{4}}$ - there was no obligation to make foreign exchange available for the liquidation of balances which had been substituted for capital investment. Between the concession that the compensation, even if in local currency, must be something more than merely formal compensation and the contention that lack of foreign exchange resources does not limit the power to nationalize or expropriate lies an area almost wholly undefined. In a sense, this lack of definition is fortunate. It means that specific cases have not arisen which would put to the test what such countries as Canada would consider to be satisfactory compensation to a foreign national; which in turn means that these countries have not expropriated American investments. Nor, fortunately, are they likely to do so.

When one turns away from what may be hoped is this theoretical definition of the right to take foreign-owned private property, and examines those cases in which theories have recently been put into practice, the situation is more complicated and less hopeful. In the cases of Yugoslavia, Czechoslovakia, Poland and the ex-enemy satellites, the problem of compensation has complications in addition to an exchange shortage. In these countries, private ownership, at least of industry, is apparently regarded as an evil to be eliminated; and the private owner is treated-if not formally classed-as an enemy of the state. ${ }^{15}$ Much happens, if reports can be believed, to the private owner who is a national of the country other than mere loss of his property. The recent purges in Czechoslovakia were reportedly designed to break the power and the position of the property-owming middle class. Under these circumstances, it would be surprising if the attitude of the local government were not one of disregard for the rights of foreign property owners. The Eastern European countries have proceeded with nationalization measures not only in disregard of

currency of the investor? How would such a situation be affected by the exchange controls of both interested countries? Would the investor have the right to insist on compensation in local currency rather than in his national currency?

${ }^{4}$ The Articles in some cases limit capital withdrawals or permit the use of restrictions on such withdrawals by the International Monetary Fund. Articles of Agreement of the International Monetary Fund, Art. VIII, Sec. 2, Cmd. 6546 (H.M. Stationery Office, 1944).

is Although no country other than the Soviet Union seems to have totally abolished the institution of private property. But cf. Doman, op. cit. supra note 4 , at II 26 . 
foreign rights, but on occasion apparently have based their action on foreign ownership. Roumania, for example, justified her nationalization law of June II, I 948 by the statement that "the nationalization . . . consolidates our economic and political independence, fortifies the forces in their struggle against the attempt at interference in our internal affairs and rape of our independence, carried on by the Anglo-American imperialists."

The result is, as a practical matter, that settlements with countries that have recently nationalized foreign private investments have to take into account two problems: the hostility of these countries toward the foreign private investor and their unwillingness-in fact if not in theory-to recognize his right to compensation; and the actual shortage of foreign exchange. The one problem complicates the other; for, while an investor might be willing to take Canadian dollars or British pounds as compensation, and to reinvest these funds in the country, no possibility of reinvestment or use is available or feasible in the Eastern European countries. From the viewpoint of a country seeking to protect the rights of its nationals, these problems may be practically stated as the problems of (a) how to get the nationalizing country to sign a compensation agreement; and (b) how to make it possible for the nationalizing country to pay in foreign exchange. The United States-Yugoslav and the United KingdomCzechoslovak settlement agreements show different techniques for the handling of these problems.

II

In both the United States-Yugoslav and the United Kingdom-Czechoslovak agreements, the inducement for the nationalizing country to enter into the agreement was identical with the means of payment.

There is little doubt that, as of the summer of I948, the United States would not have been able to obtain a compensation agreement with Yugoslavia had it not been for the presence in the United States of some $\$ 46$,800,000 of Yugoslav gold, blocked by United States law. This was gold which had been in the United States prior to the war. It was originally blocked by the Treasury Department to prevent the Germans or a German-dominated Yugoslav government from obtaining possession of it. ${ }^{36}$ After the war, Yugoslavia demanded that the gold be released. The United States refused to unblock the gold. Yugoslav action via the United Na-

${ }^{16}$ Administration of the Wartime Financial and Property Controls of the United States Government 3 (Treasury Dept., I942). The Treasury Department avoided precise definition of the purposes of the blocking, assertedly in order to achieve flexibility in administration. Alk and Moskovitz, Restoration of the Law and Property Rights after World War II 3 (I948) (paper presented at Second International Conference of International Bar Assn.). 
tions was unavailing. It was only when American claims against Yugoslavia-both the claims of American nationals arising out of nationalization and lend-lease and other governmental claims-were discussed together with the gold issue that Yugoslavia was able to achieve release of the blocked gold.

The United States thus possessed a potent negotiating point-possession of almost $\$ 47,000,000$ of Yugoslav gold at a time when Yugoslavia desperately needed foreign exchange. Not only was the gold a powerful inducement to Yugoslavia to enter into negotiations looking toward settlement of American claims, but it also provided a source of foreign exchange from which those claims could be paid. Thus, the settlement obligated Yugoslavia to turn over $\$ I \eta, 000,000$ to the United States within forty-five days of the date of the agreement. ${ }^{17}$ This sum could be and presumably was obtained through liquidation of the unblocked gold. A collateral point of no little interest was the fact that the gold was released by the United States with no restrictions, and might, therefore, be disposed of in the free gold market. In that market, prices have long been considerably in excess of the Treasury price of $\$ 35$ per ounce.

In the United States-Yugoslav case, the blocked gold provided both an inducement for Yugoslavia to enter into an agreement and a means of obtaining dollar funds with which to make payment. In the United Kingdom-Czechoslovak case, there was no such inducement. There was, however, a prospective trade agreement between Czechoslovakia and the United Kingdom. The compensation agreement provided that Czechoslovakia was to pay, toward her obligations to Britain arising out of nationalization of British-owned property, the sum of $£ 8,000,000$ over the next ten years; $;^{\mathrm{x}}$ but Britain was to permit the importation annually of $£_{5,750,000}$ of Czech manufactured goods, not falling in the category of essential goods, which were otherwise and separately scheduled.9 The British, thus, did essentially what the United States had done: that is, held out both an inducement to enter into a compensation agreement and a means by which the nationalizing country might obtain foreign exchange with which to make payments. The difference is that the inducement and the means of payment was a trade agreement-a trade agreement of a type into which the United States is not prepared or is unable to enter. ${ }^{20}$ It may be remarked that the Swiss have also been fairly

r7 United States-Yugoslav Agreement, Art. I.

${ }_{18}$ British-Czechoslovak Agreement, Arts. III, IV.

19 Trade and Financial Agreement, Art 5, op. cit. supra note 2.

${ }^{20}$ See text at note 43 et seq. infra. 
successful in working out compensation agreements with the Eastern European countries. They, like the British, have used the technique of tying together trade agreement and compensation negotiations. The pattern seems to be one which has been fairly successful, but, for the United States, it is a difficult one to emulate.

III

Although the pattern of linking the inducement and the means of payment is similar in the British and the United States agreements with Czechoslovakia and Yugoslavia, there are, as has been pointed out, substantial differences in content. Similarly, there are a great many differences in the techniques, method, and even draftsmanship of the two agreements.

\section{a) Method of Payment.}

The United States obtained lump-sum payment from Yugoslavia; Britain will receive installments, covering a period of nine years, and scheduled to begin in September, 1950. Obviously, the source of the funds with which payment was to be made is the basis for this difference: the Yugoslavs could have their money ready in forty-five days because they could liquidate the unblocked gold; the Czechs are on a pay-as-you-earn plan.

\section{b) Amount of Payment.}

The relevant question here is to what extent claims were covered. Neither the United States nor the United Kingdom has published figures indicating the amount of the claims of its nationals which it put forward..$^{2 x}$ Such figures, in any case, would be of necessity mere approximations, partially because all claims have probably not been reported, and more so because those which have been reported will in many cases have been inflated. It is commonly rumored that the $\$ I 7,000,000$ received by the United States from Yugoslavia will cover all claims allowed by the Commission to be set up for this purpose. ${ }^{22}$ In fact, the United States-Yugoslav agreement contains a provision for recapture of unused funds by Yugoslavia in case claims allowed do not equal the $\$_{17} 7,000,000$ paid. ${ }^{23}$ No similar provision is found in the British-Czech agreement.

21 The Treasury Department's wartime census of property abroad owned by nationals of the United States indicated a total of $\$ 50.3$ million in property of all types in Yugoslavia. Census of American-Owned Assets in Foreign Countries 68 (Treasury Dept., r947).

22 But see Hearings before the House Committee on Foreign Affairs on H.R. 4406, 8ist Cong. Ist Sess., at 7 (I949): "The settlement represents about $42.5 \%$ of the amounts originally claimed." Statement of Jack B. Tate, Acting Legal Adviser, Dept. of State. Mr. Tate pointed out that these claims had not been adjudicated, and that the $\$ 17,000,000$ would probably cover the "fair value of the claims." Ibid., at 7 and 18 .

${ }_{23}$ Art. I (c). 


\section{c) Eligibility.}

There is a striking difference between the standards for eligibility of claimants set up in the two agreements. Clearly the Yugoslavs had more reason to insist on a narrow definition of the eligible claimant than had the Czechs, since the Yugoslav agreement, as pointed out above, leaves open the possibility of an eventual recapture of the balance of the $\$ 17,000,000$ over the claims allowed. Since no provision of this sort exists in the British-Czech agreement, Czechoslovakia had no reason to concern herself, after the amount to be paid had been fixed, with the matter of the eligibility of claimants. Insofar as expansion of the definition of eligible claimants might correspondingly expand the amount to be paid, of course, both of the nationalizing countries would have been concerned to keep the category of eligibles narrow. A somewhat counterbalancing factor here would have been the desirability of settling all claims at once, and the obvious identity in scope between the claims eligible to receive payment and those discharged. ${ }^{24}$

Article 2 of the United States-Yugoslav agreement confines eligibility to claims of persons who were American nationals at the time of taking, ${ }^{24 a}$ or to corporations organized in the United States, provided that at least twenty per cent of a corporate claimant's outstanding securities, of any class, were owned, directly or indirectly, by American nationals. The ownership by the American national or corporation can be held directly or indirectly. For example, if an American national owned five per cent of the stock of a Swiss corporation, which in turn owned the stock of a Yugoslav corporation, the property of which was nationalized, the American national would be an eligible claimant against the fund.

The British approach is a simpler one. The test is whether the claim is one of a British national. Under the agreement, British nationals are individuals who are British citizens, and all companies, firms or associations incorporated or constituted under the laws of the United Kingdom or any

34 The British, however, agree not to press against Czechoslovakia "any claims arising out of the various Czechoslovak measures on behalf of any persons whether included in the definition of British nationals or not." Art. III (b).

240 The Senate adopted an amendment to the proposal implementing legislation, which departs from this usual requirement of international law, and provides that in any future nationalization-compensation agreements, the term "nationals of the United States" shall include persons who, at the time of the taking, were permanent residents of the United States who had declared their intention to become citizens. S. Rep. 800, 81st Cong. Ist Sess., at 2 (1949); 96 Cong. Rec. 1836 et seq. (I949).

It will also be noted that, contrary to the usual rule of international law, persons who had dual nationality are not excluded from eligibility as claimants. Persons who were still Yugoslav nationals under Yugoslav law at the time of the taking are thus eligible claimants if they were at that time citizens of the United States under American law. 
of its territories. British nationality, as so defined, must have been possessed both at the time of the taking and at the time of signature of the agreement. ${ }^{25}$ Thus, it is not necessary to inquire into the beneficial interest in a corporate claimant-a test which may complicate matters under the United States-Yugoslav agreement. Article I of the British-Czech agreement also states, rather more casually than does the similar provision of the United States-Yugoslav agreement, that the property covered by the agreement may have been owned "directly or indirectly, in whole or in part, and ... legally or beneficially" by British nationals. This would seem to come out to the same place as does the United States-Yugoslav agreement, since both agreements protect the person or eligible corporation which held its nationalized interest through holdings in one or more other corporations or juridical entities.

The twenty per cent rule of the United States-Yugoslav agreement follows the American practice of protecting only substantial, individual American interests. ${ }^{26}$ Logically, the rule could be extended so as to eliminate the corporate claimant entirely, and to allow the individual national to claim only for his aliquot share of the nationalized property. Such a rule would indeed cause administrative as well as other difficulties. Moreover, since debt claims are not covered by the agreement, ${ }^{2{ }_{a}}$ it would eliminate a claim on behalf of a United States-domiciled corporation, even though all of its bonds and debentures were in the hands of American investors, and, to make the example more striking, even if the corporation were in fact bankrupt, so that it equitably belonged to its creditors. The twenty per cent rule is a compromise between the desire to protect and the feeling that a corporate entity, whose only connection with the United

25 British-Czechoslovak Agreement, Art. I (b).

${ }^{6}$ On April 22, 1924, the Department of State informed the American Commissioner on the United States-Mexican Mixed Claims Commission: "It is believed to be a correct conclusion that a corporation organized under the laws of the United States, or of one of the constituent States, may be deemed an American national, regardless of the nationality of its stockholders. ... (Vol. 6, Moore's Digest, p. 64r) ... [1]n the light of the terms of the Joint Resolution ... it is reasonable to conclude that 'claims of American citizens' embraced claims of corporations incorporated in the United States." 5 Hackworth, Digest of International Law 832 (I927). Nevertheless, in passing on the eligibility as a claimant of a British-owned American corporation under the Conventions of 1923 with Mexico, the State Department held: "The Department concurs ... that claims of American corporations, regardless of the nationality of the owners of the shares, could be filed. ... However, it has been the long standing practice of the United States to refrain from pressing diplomatically the claims of American corporations in which there was no substantial American interest. The Department does not consider it proper for the Government of the United States to seek to protect, under the cloak of American corporations, interests which are wholly alien." 5 Hackworth, Digest of International Law 839 ( 1927$)$.

26a That is, a creditor is given no direct rights against the fund set aside for claimants. See text at note 3 I concerning the effect of the agreement on creditor interests. 
States is its establishment under our laws, is not entitled to protection abroad by the government of the United States. It reflects the practice of protecting the interests of an American corporation, despite majority foreign ownership, if there is a substantial American interest in the corporation. The British, on the other hand, apparently follow the simple rule that a locally incorporated entity is a British national, and appear willing to champion the cause of a British corporation, whoever its stockholders may be. Although it is desirable to have some rule which will prevent incorporation in the United States merely for the sake of future American protection, it would seem, in the ordinary case, that a state which allows foreigners to form a business entity within its borders might well take the attitude that it will assist such an entity. Several agreements have been interpreted to comprehend the claims of such corporations. ${ }^{27}$ In any case, the rule of the United States-Yugoslav agreement is one which depends necessarily on the arbitrary drawing of a line, and there is little more reason for a twenty per cent than a fifteen or a fifty per cent rule. In settlements growing out of recent nationalizations, the British rule may well be the better one.

A further problem of eligibility, which arises if two or more governments make compensation agreements with a nationalizing country, should be briefly pointed out. In illustration: the United States and Switzerland ${ }^{28}$ both have agreements with Yugoslavia. Yugoslavia is obligated, under its agreement with the United States, to pay for indirect interests of American nationals. Such interests may be held through a Swiss corporation, which itself has a claim against Yugoslavia. Presumably, under these circumstances, the amount to be paid to Switzerland in a Swiss-Yugoslav arrangement, on the basis of the claim of the Swiss corporation, will take into account the funds available in the United States for payment to the American stockholder. It will obviously be necessary, also, for some arrangement to be entered into between the American stockholder and the Swiss corporation, under which the American stockholder will not benefit both from payment to him directly from the funds in the United States and from payment to the Swiss corporation. Since a Swiss-Yugoslav agreement does exist, this problem is not a merely theoretical one. The solution may lie in an arrangement to be worked out between the stockholder and the corporation, under which recovery directly by the stockholder would accrue eventually to the benefit of the corporation. In the

${ }^{27}$ See note 26 supra.

\footnotetext{
${ }^{28}$ The Swiss-Yugoslav Agreement was concluded shortly after the United States-Yugoslav Agreement.
} 
absence of such agreement, remedial action of a complicated sort would presumably have to be taken directly by the Swiss corporation. In view of the clear inappropriateness of a double recovery by the stockholder to the detriment of other stockholders in the corporation, it may be that such agreements can be worked out. It may be, however, that in a particular case an American stockholder will feel that he is better off if he takes his direct recovery, retains it, and allows the corporation to revise its financial structure in order to exclude him from participation in the corporate recovery.

The question of possible double payment is naturally of interest to the nationalizing country also. Thus, Yugoslavia has insisted on deducting, from the amounts payable to Swiss corporations under its agreement with Switzerland, the amounts paid or to be paid to other governments on behalf of the interests of stockholders in such Swiss corporations. ${ }^{29}$ The Czechs have recognized the capacity of a British corporate claimant on behalf of all of its stockholders, British or otherwise. Czechoslovakia would therefore presumably insist, in any agreement with the United States, on eliminating the claims of American nationals whose interests in nationalized property derive through British corporations. This position would seem logical. On the other hand, the United States has not followed the British-Czech theory of corporate eligibility to claim regardless of the nationality of the shareholders. The United States has, in the Yugoslav agreement, insisted on its right to represent an American interest derived through the holding of stock in a third-party corporation; and the American stockholder in a British corporation may well prefer dollar to sterling compensation. The situation thus presented, which largely arises out of the different theories as to corporate eligibility, may in the future be the source of substantial complications.

Another problem of eligibility concerns the situation of the trustee. Is a British or American trustee, all or part of whose beneficiaries are foreign nationals, entitled to claim under the $\mathrm{Czech}$ or Yugoslav agreements? In the British-Czech case, the answer would presumably be in the affirmative. If a British corporation, all of whose shareholders are foreign nationals, is eligible, so also should be a British trustee for foreign beneficiaries. In the United States-Yugoslav case, the answer may be the opposite, if all of the beneficiaries are foreign. ${ }^{30}$ If the corporate analogy is used,

29 As reported by reliable Swiss sources.

${ }^{30}$ See 5 Hackworth, op. cit. supra note 26, at 850-5I, citing decision of Mixed Claims Commission, United States and Germany (claim of executors of estate all of whose beneficiaries were French nationals held "not impressed with American nationality"). 
the American trustee would be able to recover against the fund which has been established if twenty per cent of the beneficial interest in the trust were American. Just how such a rule would work out in relation to contingent interests and other possible uncertainties with respect to the ultimate vesting of the trust res is again a problem not handled in the agreement but likely to cause future controversy.

\section{d) Debt Claims.}

The British-Czech agreement deals only with'ownership interests, and does not mention debt claims. The United States-Yugoslav agreement deals only with a particular category of debts. Under both the BritishCzech and the United States-Yugoslav agreements, the ordinary debt claimant is left in statu quo, being free to present his claim to the nationalized company. Under present circumstances, he can have little cause for optimism about his chances for collection, or for conversion of the amount collected into foreign exchange. It may be that in certain circumstances the creditor can present his claim to the compensated owner rather than to the nationalized company. There is some logic in this approach in a few cases under the United States-Yugoslav agreement, but evidence that it was intended in the British-Czech agreement is lacking.

The American-Yugoslav agreement deals with the problem of debt claims, though with one exception, it may be doubted that it does much for the creditor. The exception occurs in the case in which American creditors own twenty per cent or more of the outstanding debentures, bonds, or other class of credit security of an American corporation which would not otherwise be an eligible claimant. In that situation, the corporation becomes an eligible claimant, ${ }^{3 x}$ and the creditor will presumably be able to recover from the proceeds of the corporate claim. The requirement of the agreement that the American national or nationals own "[t]wenty per cent or more of any class of the outstanding securities" (emphasis added) seems to protect the debenture or bondholder but to leave unprotected any creditor who does not hold corporate securities.

So far as other creditors are concerned, the agreement provides for recognition by Yugoslavia of the liability of successor organizations for debts which were validly incurred prior to nationalization. The agreement provides that Yugoslavia shall authorize Yugoslav debtors to meet debts "to any individuals, firms or governmental agency in the United States." 32 Whether the omission of any direct reference in this text to corporations is

${ }^{3 \mathrm{~A}}$ Art. 2 (b).

33 Art. to (a). 
intentional is not determinable from the agreement. Corporations may be included within the term "firms." It is possible that the language used in Article to is different from that in that portion of the agreement dealing with ownership interests because the obligation with respect to debts is meant to run to any person or business entity in the United States, whether or not that person or business entity can be considered a national of the United States. Thus, the obligation under Article ro would seem to include the payment of debts owing to foreign residents of the United States; and avoidance of special reference to corporations may merely reflect the understanding that a nationality test, of the twenty per cent kind elsewhere used, is not applicable in this type of situation.

Article ro (b) of the Yugoslav agreement also imposes an obligation on Yugoslavia, in certain circumstances, to make foreign exchange available in payment of what are thus considered to be American debts. The circumstances, however, are not such as to make it likely that foreign exchange payments will be made in many cases. The obligation exists only (a) "to the extent feasible," (b) "considering Yugoslav foreign exchange resources and regulations," (c) "when necessary to effectuate the purposes of" the paragraph calling for payment of debt claims, and (d) only with respect to legally incurred "dollar obligations arising from commercial transactions involving goods or services." These provisions, even so hedged about, may be better than the blank which exists in the BritishCzech agreement; but they hold no real promise, particularly since there is no standard provided for the "Yugoslav foreign exchange ... regulations" which Yugoslavia may take into consideration.

In another respect affecting creditors, the American agreement with Yugoslavia appears more thoughtful than the British agreement with Czechoslovakia. The United States has provided that the American who receives compensation for the nationalization of his property shall assume all debt obligations, existing as of the date of the agreement, not incurred for the benefit of the nationalized enterprise. ${ }^{33}$ The assumption of debts, of course, is proportionate to the ownership interest for which compensation is received. This provision apparently arises from the assertion that the shareholders sometimes caused corporations they controlled to assume obligations which brought benefits to the shareholders but not to the corporation. Under these circumstances, it was felt that the person who receives the assets or their value should, equitably, be understood to have assumed the debts; and on this theory, the British may intend the same results. Like other clauses of the agreement, this one appears des-

33 Art. 4 (b). 
tined to cause disputes. If an American owned forty per cent of a nationalized enterprise, is he liable for forty per cent of the debts, even if he derived no benefit from the transaction in which a stockholder's obligation was assumed by the corporation? Is the amount of the debt to be reduced to the same degree that he fails to receive full compensation? How is his obligation to competing creditors to be ascertained or measured, if more than forty per cent of the outstanding debt claimants call on him for payment? Is there to be a first-come, first-served rule, or a rule which allocates the funds available for debt payment among all comers on a proportionate basis? Is there to be any preference for American as against foreign creditors? To none of these questions does there seem to be a clear-cut answer. The Commission which is to be established to administer the Yugoslav agreement will perhaps have to consider and rule on these questions, and on others which will undoubtedly come to the surface as specific cases are processed.

One portion of the United States-Yugoslav agreement would seem to reflect either carelessness or a rather surprising, if intended, result. The agreement provides that "there shall be deemed fully settled and discharged all debt obligations of enterprises, nationalized or otherwise taken, owing to nationals of the United States whose claims against the Government of Yugoslavia with respect to the nationalization or other taking of such enterprises are claims which are fully settled and discharged by this agreement...."34 This seems to say that if an American national owned a few shares of stock in a nationalized enterprise, no matter how few the shares or small the value of that stock interest, he is barred from pressing a debt claim which he may have had against the same enterprise, no matter how large that claim. If, of course, other American nationals owned the remainder of the stock, he may be able to try to collect from them. But if he happened to be a substantial creditor and a small stockholder, and if the other stockholders are not American, he apparently has lost his substantial debt claim by being eligible to recover on his small ownership claim. ${ }^{34 \mathrm{a}}$

Like other clauses of the agreements, this case indicates a failure to meet the problems of creditors. This failure may well be at least partially attributable to a mode of thought which has traditionally looked toward the protection of ownership rather than creditor interests. This seems to

34 Art. 4 (c).

${ }_{34^{4}}$ Since, under Yugoslav law, the debt claim of a shareholder may be considered to represent an equity rather than a credit interest, it is possible that his debt obligations may be deemed to be a claim "with respect to nationalization," and therefore eligible for payment under the agreement. 
be an unrealistic attitude. Stockholders may have little financial interest in a corporation, while creditors may have the real equitable and financial interest in the corporation and its properties.

While it is difficult to prescribe for this situation, it does seem clear that more attention will have to be given to this aspect of the protection of interests in foreign-located property. In any case, it cannot be said that these problems are made easier by ignoring them, as is done in the British-Czech case. To the extent that the United States-Yugoslav agreement delimits the problem by inking in the outlines of an equitable principle of assumption of debts, it helps in the solution of a number of what will be troublesome problems. But, in at least one case it seems to achieve an undesirable result; and it does not go very far in the direction of clarification of the status of a creditor interest, perhaps because the lump-sum compensation agreement is an unfamiliar, post-World War II phenonemon.

e) Other Matters.

Within this general rubric may be included a variety of points treated in the United States-Yugoslav but not in the British-Czech agreement. The United States was apparently concerned with future treatment of American property in Yugoslavia. Article 5 binds Yugoslavia to mostfavored-nation treatment, in accordance with the provisions of the United States-Serbian Treaty of I88I. The agreement prevents the Yugoslav successor organization from using a trademark, outside of Yugoslavia, if that trademark is used by the former American owner, and if the nationalized American "substantially owned, directly or indirectly" the trademark. ${ }^{35}$ A definition of substantial ownership is not provided. Finally, war damage claims of Americans are to be treated no less favorably than the similar claims of Yugoslav nationals, as well as on a most-favored-nation basis. ${ }^{36}$ The British-Czech agreement touches on none of these matters.

The administrative provisions of the two agreements are essentially similar. Britain and the United States are both to collect probative material and to supply it to the Czechs or Yugoslavs. ${ }^{37}$ Both have the commitment of the other parties to aid in the establishment of the claims. ${ }^{38}$ Per-

${ }^{35}$ Art. 6. It will be noted that, in dealing with trademarks, the agreement speaks only of "nationalization" and not of "other taking," a phrase which is used elsewhere. This apparently leaves the nationalized company free to use trademarks owned by companies which were owned by American companies via German subsidiaries. In these cases the Yugoslav properties were sometimes vested as enemy, rather than "nationalized."

${ }^{36}$ Art. 7.

37 British-Czechoslovak Agreement, Art. V; United States-Yugoslav Agreement, Art. 9 (b). 9 (a).

${ }^{38}$ British-Czechoslovak Agreement, Art. VI; United States-Yugoslav Agreement, Art. 
haps characteristically, the obligation resting on Yugoslavia in this respect is more carefully-or more wordily - spelled out than is the obligation of Czechoslovakia. The latter shows a typically British terseness. In most other respects, despite certain differences in method and phrase, the two agreements are similar. However, the United States-Yugoslav agreement gives to Yugoslavia the right to file briefs with the Commission which is to be set up to administer the agreement ${ }^{39}$-a right which is clearly irrelevant to the British-Czech agreement, under which no possibility of a reverter of surplus proceeds exists. The right may be availed of and may be important, particularly if it appears that determination of some of the open questions which have been pointed out may so affect the totals as to make a refund possible.

\section{IV}

The drawing of conclusions and the spinning out of inferences from materials such as those handled in this article is a dangerous business. The materials are too fragmentary to permit of easy generalization, despite the existence of a handful of other international agreements like the two which have been analyzed. Eastern Europe is not the world, and the handling of a nationalization problem vis-à-vis Czechoslovakia may be entirely different from the handling of a similar problem vis-à-vis a non-Eastern European state. Even within the Eastern European Communist area there are certain notable differences in policies and attitudes. Any conclusions must therefore be of a limited sort. But, since nationalization problems do exist between the United States and many of the countries of Western Europe, on the one hand, and Eastern Europe, on the other, it may be helpful to peer a short way into the darkness with the aid of the light shed by the Czech and Yugoslav agreements.

First. It is obvious that the over-all compensation agreement, in which a settlement is reached on a government-to-government basis, and in which the ex-property owner receives a claim against his own rather than the nationalizing government, is likely to be used in future settlements. It seems effectively to have displaced settlements in which individual awards are made dependent on proof to be presented to a mixed arbitral tribunal, or in which the amount of the total liability of the nationalizing government is not fixed. The tentative agreement initialed some two years ago between the United States and Poland, ${ }^{40}$ it is true, did not fix a total to

${ }^{39}$ Art. 9 (b).

40 Agreement "in principle" on a compensation arrangement was worked out between Poland and the United States in I947. The agreement provided for presentation of American 
be paid to the United States for distribution; and under that agreement, an American claimant would have been put to his proof before other than American authorities. Reasonable as such a settlement might have been in other ways, it does not fit a situation in which the street invective of the past is the diplomatic usage of the day, and in which willingness to pervert judicial procedures is the mildest of the charges hurled between East and West. It is difficult to imagine that the State Department would in fact and at present sign an agreement which granted rights to compensation conditioned on proof before Polish authorities. Perhaps in the future, under other political conditions, such agreements may again be used. They may be used even now in relation to countries other than those of Eastern Europe. But the over-all type of settlement, with the claimant government receiving the compensation directly and then allocating it among its nationals, is more likely to see extensive use if, indeed, any settlements at all are negotiated.

The political factors are not the only ones which favor the over-all type of settlement. When the class of claimants is large, even with the best of intentions on both sides, the procedure of putting claimants to their proof before the government which is to make payments may be not satisfactory. The establishment of effective administrative procedures for the adjudication and payment of claims is not an easy task. The United States is having its difficulties in deciding how to pay out the funds received from Yugoslavia..$^{4}$ Where the administrative machinery has to be set up within the framework of a foreign government, and where that machinery is to handle large numbers of claims on an individual basis, delays are likely to ensue. Thus, war damage claimants ${ }^{42}$ under the Treaty of Peace with Italy seem as far away from payment today as they were when the Treaty was ratified. A certain amount of precision in the determination of the exact total due to American claimants might be sacrificed if Italy and the United States were to agree on a lump sum settlement, with that sum subsequently allocated among claimants by the United States. But, recognizing that American administrative machinery is not always rapid, payments would probably be more rapid than under present procedures. And, should there be unwarranted delays, it is clear that

claims for adjudication in Poland, under accepted governing principles. The agreement foundered, it may be surmised on United States unwillingness to include loans and export licenses as part of the price of the agreement.

${ }_{4 x}$ The bill designed to put the United States-Yugoslav agreement into operation and to set up a Commission to administer it, passed the House in the first session of the 81st Congress.

4 Compare Italian Treaty of Peace, Art. 78. 
claimants can make their voices heard and effective more easily when the desired action is within the province of the United States than when the United States can merely prod another government.

On both these counts, then, the over-all settlement, as broadly exemplified in the United States-Yugoslav or British-Czech agreements, would appear to be a probable future mold.

Second. Even this relatively casual study of two recent agreements indicates that the technique of the over-all settlement is one which has hardly been completely mastered; even passing the conflicting theories with respect to corporate eligibility, there are fundamental and unresolved problems which arise out of the agreements. The role of debt claims is one such question. Some of the interpretative difficulties have been outlined. It would appear necessary that substantially more thought be devoted to the technique of the over-all agreement and its attendant problems. As it is, the role of the bodies set up to administer the agreements is likely to be more legislative than judicial. Questions of interpretation will arise under any agreement; but their number and scope can be reduced.

Third. The over-all agreement is a useful technique. But, if the analysis of this article is a correct one, it is a technique which has its limits, at least for the United States. For the heart of the over-all agreement is its ability to proffer both an inducement to enter into agreement and a means of making payment. In the Yugoslav case, the United States had the blocked gold to use as this inducement and means. The British were able to offer to open their market to nonessential $\mathrm{Czech}$ products which would otherwise have been barred. But the United States does not have substantial amounts of blocked property of other Eastern European countries; nor does the United States prevent the entry of any legitimate foreign products into the American market, except in the case of a few agricultural quotas. Moreover, to use quantitative restrictions on imports into the United States would be to go contrary to established American governmental and trade patterns ${ }^{43}$ The United States would presumably be most reluctant to take such a step and enter the ranks of those utilizing quantitative restrictions, even to a sharply limited extent and only vis-à-vis those countries which have confiscated American properties.

Nevertheless, it may be that the United States will re-examine this situation. Roumania, Bulgaria and Hungary have some blocked funds in the United States, though not nearly to the amount of the claims of American nationals against those countries. With respect to other coun-

${ }^{43}$ Bronz, The International Trade Organization Charter, 62 Harv. L. Rev. I089, I095 et seq. (x949); Wilcox, op. cit. supra note $x_{3}$, at $x_{4}$ et seq. 
tries, the trade method is probably the only one available. If an agreement is to be worked out with Czechoslovakia or Poland, for example, it seems probable that some control over trade between the United States and these countries will have to be assumed. It would be possible for the United States-much as the step would deviate from normal trade policies-to declare that purchases of nonessentials will be embargoed unless and until an agreement is reached. The negotiations with Poland and Czechoslovakia seem to have foundered on the desire of those countries to tie up settlement of nationalization problems with relaxation of American export controls or perhaps with an American loan. No real possibilities apparently exist on that line of discussion. But possibilities may exist if the United States is willing to take the line that Czech or Polish exports of gloves, shoes and similar products to the United States will no longer provide a source of dollar earnings, unless the legitimate claims of American nationals are settled.

The possibility of developments of this sort would have to be examined in the light of American obligations under such international agreements as the General Agreement on Tariffs and Trade, as well as in the light of a traditionally liberal trade policy. The suggestion could not be made even as a basis for examination were not relations between the United States and these countries already in extremis. But, under present circumstances, it is a suggestion which may at least merit examination by the governmental authorities of the United States. 